\title{
The effect of Topotecan on oxidative stress in MCF-7 human breast cancer cell line
}

\author{
Mujgan Timur, S. Halide Akbas and Tomris Ozben ${ }^{\bowtie}$ \\ Department of Biochemistry, Faculty of Medicine, Akdeniz University, Antalya, Turkey; \\ ®e-mail: ozben@akdeniz.edu.tr
}

Received: 10 February, 2005; revised: 23 June, 2005; accepted: 30 June, 2005

available on-line: 07 November, 2005

\begin{abstract}
Purpose. Topotecan, a semisynthetic water-soluble derivative of camptothecin exerts its cytotoxic effect by inhibiting topoisomerase I and causes double-strand DNA breaks which inhibit DNA function and ultimately lead to cell death. In previous studies it was shown that camptothecin causes ROS formation. The aim of this study was to investigate if Topotecan like camptotecin causes oxidative stress in MCF-7 human breast cancer cell line. Determining the oxidant effect of Topotecan may elucidate a possible alternative mechanism for its cytotoxicity. Experimental design. MCF-7 cells were cultured and exposed to Topotecan for $24 \mathrm{~h}$ at $37^{\circ} \mathrm{C}$. The viability of the cells (\% of control) was measured using the colorimetric 3-(4,5-dimethylthiazol-2-yl)-2,5-diphenyl tetrazolium bromide (MTT) assay. Lipid peroxidation (TBARS), protein oxidation (carbonyl content), sulfhydryl, glutathione (GSH) levels, superoxide dismutase (SOD), catalase (CAT) and glutathione peroxidase (GPx) activities were determined in MCF-7 cells with and without Topotecan incubation. Results. We found the $\mathrm{IC}_{50}$ concentration of Topotecan as $0.218 \mu \mathrm{M}$ in MCF-7 cells. This concentration of Topotecan was used in the incubations of the cells. Our data indicated increased oxidative status, as revealed by increased lipid peroxidation and protein oxidation, and decreased GSH and sulfhydryl levels in MCF-7 cells exposed to Topotecan compared to control cells. In contrast, there was a slight increase in SOD and a significant increase in GPx and catalase activity in MCF-7 cells incubated with Topotecan compared to the control. Conclusions. These results support our hypothesis that Topotecan increases oxidative stress in MCF-7 cells.
\end{abstract}

Keywords: Topotecan, MCF-7 cells, breast cancer, oxidative stress, antioxidants

Breast cancer is the second most common cancer among women in developed countries (Hulka \& Stark, 1995). Although many cytotoxic agents are used in the treatment of this disease, their efficiency is limited due to several factors. Novel therapeutic agents against breast cancer are needed. The semisynthetic camptothecin analogue Topotecan [9(dimethylamino)methyl-10-hydroxy camptothecin] is used to treat a variety of malignancies (Erlichman et al., 2001). The mechanism of Topotecan cytotoxicity involves inhibition of nuclear topoisomerase I enzyme and causes irreversible double-strand DNA breaks. These DNA breaks are thought to be the lesions responsible for camptothecin-induced cell death (Kaufmann et al., 1996). Sensitivity of cells to topoisomerase I poisons is modulated by a variety of factors, including topo I content, cell cycle dis- tribution and DNA repair capability (Erlichman et al., 2001).

Numerous investigations have documented cellular changes resulting from oxidative stress induced in cells following exposure to cytotoxic drugs. Although cytotoxic agents such as doxorubicin, daunorubicin, mitoxantrone, bleomycin and cisplatin used in these studies were structurally dissimilar and acted on different cellular targets, they induced oxidative stress by generation of reactive oxygen species (ROS) in tumour cells. Formation of ROS increased the cytotoxic activity of the drugs in cancer cells via inducing apoptosis (Sinha \& Mimnaugh, 1990; Kinnula et al., 1998). $\mathrm{H}_{2} \mathrm{O}_{2}$ generation was found in the process of apoptosis induced by physiological concentrations of camptothecin (Simizu et al., 1998). There are some stud-

Abbreviations: CAT, catalase; GPx, glutathione peroxidase; GSH, glutathione; $\mathrm{IC}_{50}, 50 \%$ inhibitory concentration; MTT, 3(4,5 dimethylthiazol-2-yl)-2,5-diphenyl tetrazolium bromide); PCO, protein carbonyl; ROS, reactive oxygen species; SOD, superoxide dismutase; TBARS, thiobarbituric acid reactive substances. 
ies supporting the hypothesis that oxidative stress might modulate the cytotoxicity of camptothecin, but experiments demonstrating the effect of Topotecan on oxidative stress are very limited. Recently, Muluk et al. (2005) revealed the efficacy of Topotecan treatment on antioxidant enzymes and TBARS levels in submandibular glands of rabbits. In our recently published study, we found increased ROS and nitrite levels as indicators of oxidative stress in MCF-7 and MDA-MB-231 human breast cancer cell lines following Topotecan incubation (Akbas et al., 2005). In our present study, we expanded our investigations to the effects of Topotecan on other oxidative stress markers and antioxidants in MCF7 cells. For oxidative stress markers, we measured thiobarbituric acid-reactive substances (TBARS) as a marker for lipid peroxidation, and protein carbonyl content as an indicator of oxidative protein damage. The best marker for intracellular oxidative stress-dependent cellular damage is protein carbonyl content. High ROS level leads to protein oxidation which converts proteins to protein carbonyl derivatives (Telci et al., 2000). Oxidative protein damage cannot be repaired and causes irreversible modifications in proteins (Stadtman, 2002). The unique advantage of carbonyl measurement as a good marker for oxidative stress is the fact that it covers a much wider range of oxidative damage than other markers (Reznick \& Packer, 1994; Evans et al., 1999; Carrard et al., 2002; Cakatay et al., 2003). Other markers for protein oxidation such as nitrotyrosine, hydroxylation of aromatic and hydrophobic amino acids are at a very low level in comparison to the carbonyl content. Since oxidative stress has been defined as a loss of balance between free radical or reactive oxygen species production and the antioxidant systems, we measured antioxidants such as sulfhydryl, glutathione (GSH) and activities of antioxidant enzymes including superoxide dismutase (SOD), catalase (CAT), and glutathione peroxidase (GPx). Protein sulfhydryl (thiol) groups and the tripeptide glutathione (GSH) are particularly important for antioxidative defense in cells. Reduced glutathione (GSH) is the most abundant cellular thiol compound and an important intracellular antioxidant (Stadtman \& Levine, 2000). Measurement of protein sulfhydryl groups is useful as well as protein carbonyl content to determine oxidative protein damage.

No study has been carried out so far to show the effects of Topotecan on these oxidative stress markers and the antioxidant profile in human breast cancer cell lines. In order to clarify if Topotecan causes oxidative stress, we measured levels of TBARS, protein carbonyl content, sulfhydryl, glutathione and activities of antioxidant enzymes including SOD, CAT, and GPx in MCF-7 cells incubated with and without Topotecan.

\section{MATERIALS AND METHODS}

Cell line. MCF-7 human breast cancer cell line was kindly supplied by Dr. J. Lemontt and H.F. Pross from Queen's University in Canada. The MCF-7 cell line (estrogen receptor positive) was derived from primary breast tumor of a patient. Cells were grown in monolayer culture in minimum essential medium (MEM) supplemented with 10\% (v/ v) fetal calf serum, $1 \mathrm{mM}$ sodium pyruvate, $10 \mu \mathrm{g} /$ $\mathrm{ml}$ bovine insulin, and $1 \%(\mathrm{v} / \mathrm{v})$ antibiotic-antimycotic agent. Cells were grown to confluence at $37^{\circ} \mathrm{C}$ in a humidified atmosphere containing $5 \% \mathrm{CO}_{2}$ in air and were passaged weekly using $0.25 \%$ trypsin.

Chemicals and drugs. All chemicals were purchased from Sigma (St. Louis, MO, USA). A stock solution of $1 \mathrm{mg} / \mathrm{ml}$ Topotecan was prepared by dissolving Topotecan hydrochloride (Hycamtin ${ }^{\circledR}$, SmithKline Beecham Pharmaceuticals, Philadelphia, PA, USA) in sterile dimethyl sulfoxide (DMSO) and stored at $-80^{\circ} \mathrm{C}$. The stock solution was diluted from $218 \mu \mathrm{M}$ to $0.001 \mu \mathrm{M}$ with MEM. The final vehicle concentration did not exceed $0.5 \%(\mathrm{v} / \mathrm{v})$ either in control or in treated samples throughout the experiments.

Viability assay. The number of viable cells (\% of control) was measured using the colorimetric 3-(4,5-dimethylthiazol-2-yl)-2,5-diphenyl tetrazolium bromide (MTT) assay (Mosmann, 1983; Sladowski et al., 1993). The MTT method allows one to measure the number of viable cells in a given sample as the percentage of viable cells present in the control sample. The principle of this method is based on cellular reduction of MTT to a blue formazan product by mitochondrial dehydrogenases of viable cells. The intensity of the blue color formed by this procedure is proportional to cell viability. Cells were trypsinized and separated from the surface of the flask. Trypan Blue $(0.4 \%)$ dissolved in phosphate-buffered saline (PBS) was used for cell counting. Trypsinized cell suspension $(0.2 \mathrm{ml})$ was put in a tube and mixed with $0.3 \mathrm{ml}$ medium and $0.5 \mathrm{ml} 0.4 \%$ Trypan Blue. After $5 \mathrm{~min}$, cells were counted in a hemocytometer. Cell suspension $(0.1 \mathrm{ml})$ containing $1 \times 10^{5} \mathrm{MCF}-7$ cells was added into each well of a 96 well, flat-bottomed tissue culture microplate and incubated for 24 h. Fresh culture medium was exchanged before the addition of Topotecan. A sample of $10 \mu \mathrm{l}$ Topotecan from each dilution was added into three wells containing cells. Cells were incubated with Topotecan for $24 \mathrm{~h}$ at $37^{\circ} \mathrm{C}$. Control cells treated with medium only were applied to the same plate. At the end of incubation, MTT $(10 \mu \mathrm{l})$ at a concentration of $5 \mathrm{mg} / \mathrm{ml}$ in PBS was added into each well, the plates were wrapped with aluminum foil and incubated for $4 \mathrm{~h}$ at $37^{\circ} \mathrm{C}$. Following incubation, $180 \mu \mathrm{l}$ DMSO was put into each well, mixed and the plates were kept at dark overnight. A microplate reader (Sirios, 
Seac Radim Group, Italy) was used to measure the absorbances at $570 \mathrm{~nm}$ (Mosmann, 1983; Sladowski et al., 1993). The average absorbance values of the cells incubated with Topotecan were compared with the average absorbance values of the control cells to calculate the percentage of viable cells (\% of control). The results were given as the mean \pm S.D. of eight independent experiments performed in triplicate. The $\mathrm{IC}_{50}$ concentration of Topotecan which inhibits $50 \%$ of cell proliferation was found to be 0.218 $\mu \mathrm{M}$. This concentration of Topotecan was applied in the rest of the experiments.

Preparation of cell lysate. MCF-7 cells were incubated with the $\mathrm{IC}_{50}$ level of Topotecan whereas control cells were incubated with vehicle only for 24 h. Following incubation, cells were collected using trypsin, washed with PBS ( $\mathrm{pH}$ 7.4) three times and the pellet was transferred into extraction solution which contained $20 \mathrm{mM}$ potassium phosphate buffer ( $\mathrm{pH} 7)$ and a protease inhibitor cocktail. Cells were sonicated using a Biosonic IV sonicator with 15-s bursts for a total of $4 \mathrm{~min}$ on ice and centrifuged at $15000 \times g$ for $45 \mathrm{~min}$ in a refrigerated centrifuge. The supernatant obtained was used in the experiments.

Determination of antioxidants and oxidative stress markers. TBARS in cells were determined using the fluorometric method of Wasowicz et al (1993) and the results were expressed as nmol/mg protein. Carbonyl content in oxidatively modified proteins was determined by the method of Levine et al. (1990). Absorbance of the samples was measured at $360 \mathrm{~nm}$ and carbonyl results were given as $\mu \mathrm{mol} / \mathrm{g}$ protein using $\varepsilon_{\max } 22000 \mathrm{M}^{-1} \mathrm{~cm}^{-1}$. Sulfhydryl concentration was determined by the method of Koster et al. (1986). The method of Fairbanks and Klee (1986) was used to measure the concentration of GSH in the cells.

The spectrophotometric indirect inhibition method of Misra and Fridovich (1972) based on the ability of superoxide dismutase to inhibit autooxidation of adrenaline to adrenochrome at alkaline $\mathrm{pH}$ was used in the assay of $\mathrm{Cu}, \mathrm{Zn}$-SOD activity. Catalase activity was measured using the method of Aebi (1987) with hydrogen peroxide as a substrate. The method is based on decomposition of hydrogen peroxide which is indicated by a decrease in absorbance at $240 \mathrm{~nm}$. The coupled method of Paglia and Valentine (1967) using t-butyl hydroperoxide as a substrate was used to measure activity of GPx in cells. Protein levels were measured by the method of Lowry et al. (1951). The results were expressed as $\mathrm{U} / \mathrm{g}$ protein for SOD and GPx, and as $k / \mathrm{g}$ protein for CAT, where $k$ is the rate constant for CAT activity.

Statistical analysis. Statistical analysis was performed using Mann-Whitney $U$ test with the SPSS program for Windows version 10.0 (SPSS Inc., Chicago, IL, USA). All the experiments were repeated eight times. Mean values and standard de- viations (mean \pm S.D.) were calculated for every variable in each cell group and were compared between two cell groups treated with and without Topotecan. $P<0.05$ was selected as statistically significant.

\section{RESULTS}

\section{Cytotoxic activity of Topotecan}

The experiments were repeated 8 times and similar results obtained from these repetitions were averaged. The cytotoxic effect of different concentrations of Topotecan on MCF-7 cells is shown in Fig. 1. The inhibitory concentration $\left(\mathrm{IC}_{50}\right)$ of Topotecan for MCF-7 cells was found as to be $0.218 \mu \mathrm{M}$ using MTT assay. This concentration of Topotecan was applied for incubation of the cells in subsequent experiments.

\section{Effects of Topotecan on antioxidants and oxidative stress markers}

The TBARS level in cells incubated with Topotecan for $24 \mathrm{~h}$ showed a significant increase in comparison to the level in control cells (Table 1). A similar increase was observed in protein carbonyl levels in MCF-7 cells treated with Topotecan compared to the level found in control cells not treated with Topotecan (Table 1).

A significant decrease was observed in glutathione levels of the cells treated with Topotecan compared to the control groups (Table 1). Sulfhydryl levels of the cells treated with Topotecan were lower than the level measured in control cells (Table 1).

The superoxide dismutase activities of the cells incubated with Topotecan showed a statistically non-significant increase in comparison to the control cells (Table 1), whereas the catalase and glutathione peroxidase activities were found to be significantly higher in the cells treated with Topotecan (Table 1).

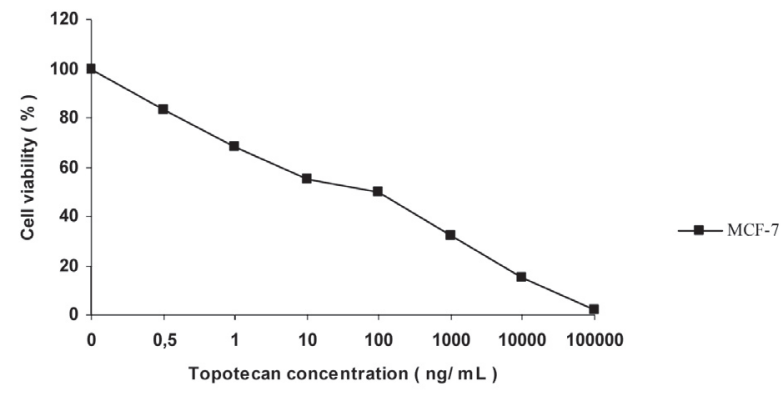

Figure 1. Cell viability of MCF-7 cells against different concentrations of Topotecan.

Cell viability experiments were done after $24 \mathrm{~h}$ of Topotecan incubation as described in Methods. The mean value of eight experiments is shown. The S.D. of the means were less than $10 \%$ and were omitted. 
Table 1. Oxidative stress markers and antioxidants in control and Topotecan-treated MCF-7 cells

\begin{tabular}{lcc}
\hline & Control & Topotecan \\
\hline $\begin{array}{l}\text { TBARS } \\
\text { (nmol/g protein) }\end{array}$ & $0.44 \pm 0.19$ & $2.37 \pm 0.32^{*}$ \\
$\begin{array}{l}\text { Protein carbonyl } \\
\text { content } \\
(\mu \mathrm{mol} / \mathrm{g} \text { protein) }\end{array}$ & $2.26 \pm 0.59$ & $4.37 \pm 0.98^{*}$ \\
$\begin{array}{l}\text { Glutathione } \\
\text { (mg/g protein) }\end{array}$ & $46.0 \pm 10.99$ & $28.30 \pm 5.95^{*}$ \\
$\begin{array}{l}\text { Sulfhydryl } \\
\text { ( } \mu \text { mol/g protein) }\end{array}$ & $5.60 \pm 1.07$ & $3.88 \pm 0.55^{*}$ \\
$\begin{array}{l}\text { Cu,Zn-SOD } \\
\text { (U/g protein) }\end{array}$ & $47765 \pm 15637$ & $69105 \pm 27497$ \\
$\begin{array}{l}\text { Catalase } \\
(k / g \text { protein) }\end{array}$ & $162.94 \pm 30.48$ & $223.86 \pm 30.73^{*}$ \\
$\begin{array}{l}\text { Glutathione peroxi- } \\
\text { dase (GPx) } \\
\text { (U/g protein) }\end{array}$ & $7.26 \pm 0.87$ & $11.59 \pm 1.80^{*}$ \\
\hline
\end{tabular}

The results are expressed as mean \pm S.D. of eight experiments. ${ }^{*} P<0.05$ : significantly different compared to the controls.

\section{DISCUSSION}

It is known that some cytotoxic agents with different structures and targets other than Topotecan increase the levels of ROS. Chemotherapeutic agents such as doxorubicin, daunorubicin, mitoxantrone, bleomycin, and cisplatin promote oxidative stress by generating ROS (Russo et al., 1984; Novak \& Kharasch, 1985; Baliga et al., 1999; Mansat-de Mas et al., 1999; Hagiwara et al., 2000; Minotti et al., 2001; Baek et al., 2003). Doroshow (1986) and Sinha et al (1987) proposed that oxygen free radicals generated by adriamycin may be directly related to their cytotoxic effect in MCF-7 human tumour cells. These researchers found that the cytotoxicity of these drugs in MCF-7 cells was diminished by supplementation with radical scavenger antioxidants. In their studies, Gorman et al. (1997) showed increased ROS formation in a promyelotic leukemia HL-60 cell line after treatment with camptothecin and SN-38 which is an analogue of camptothecin. Exogenous catalase supplementation decreased the cytotoxic effects of these drugs in these cells. Wenzel et al. (2004) tested the effects of ascorbic acid on apoptosis which was induced by two potent apoptosis inducers, the classical anti-tumour drug camptothecin and a flavonoid, flavone, in HT-29 human colon carcinoma cells. They found that camptothecin and flavone increased generation of mitochondrial superoxide which preceded the downregulation of bcl- $\mathrm{X}_{\mathrm{L}}$. Ascorbic acid at $1 \mathrm{mM}$ concentration prevented generation of superoxide, thereby blocking drug-mediated apoptosis (Wenzel et al., 2004). Somasundaram et al. (2002) in their tissue culture studies revealed that curcumin inhibited camptothecin-, mechlorethamine-, and doxorubicin-induced apoptosis in MCF-7, MDA-MB-231, and BT-474 human breast cancer cells by up to $70 \%$. They found that under these conditions, curcumin exhibited antioxidant properties and inhibited chemotherapy-induced apoptosis through inhibition of ROS generation and blockade of the cJun $\mathrm{NH}_{2}$-terminal kinase (JNK) pathway. Although it is proposed that camptothecin induces apoptosis via superoxide formation, the mechanism of ROS formation by camptothecin remains to be further clarified. Simizu et al. (1998) demonstrated that inhibition of NADPH oxidase by diphenyleneiodonium chloride supressed both camptothecin-induced apoptosis and camptothecin-induced $\mathrm{H}_{2} \mathrm{O}_{2}$ production in both SCLC and leukemia cells. These results indicate that NADPH oxidase increase $\mathrm{H}_{2} \mathrm{O}_{2}$ generation during camptothecin-induced apoptosis. Hiraoka et al. (1998) investigated the role of phagocyte NADPH oxidase in apoptosis in human leukemia and in neutrophilic-differentiated cells and found that generation of ROS by NADPH oxidase may be related directly or indirectly to camptothecin-induced apoptosis. Although it is known that camptothecin induces ROS formation, no study so far has been carried out to show the effects of Topotecan on the oxidative stress markers and antioxidant profile in human breast cancer cell lines (Hiraoka et al., 1998). There is also no data or study about the interaction of Topotecan with cellular enzymes involved in ROS formation.

Our data showed that lipid peroxidation expressed as TBARS increased in MCF-7 cells treated with Topotecan. Similar results with different drugs were reported by other researchers. Bustamante et al. (1990) reported increased lipid peroxidation in MCF7 cell lines treated with adriamycin.

In our study, we found significantly higher protein carbonyl (PCO) levels in Topotecan treated cell lines compared to the control cells which contained only vehicle. On the other hand, levels of protein sulfhydryl groups and of GSH were significantly lower in Topotecan treated cells in comparison to the control cells. The decrease in GSH and protein sulfhydryl groups might be due to increased oxidation of thiol groups to struggle with high ROS levels in cells incubated with Topotecan. These data support our hypothesis of increased oxidative stress in MCF-7 cell lines incubated with Topotecan. Similar results were observed by other researchers. Geng et al. (2003) treated SMMC-7721 human hepatoma cell line with docetaxel for $24 \mathrm{~h}$. They found that levels of ROS significantly increased, while levels of glutathione significantly decreased. Hug et al. (1997) reported that the treatment of HEPG2 hepatoma cell line with bleomycin caused GSH depletion and generated ROS. Mans et al. (1992) showed that GSH depletion increased sensitivity to etoposide.

In our study, $\mathrm{Cu}, \mathrm{Zn}-\mathrm{SOD}$ activity in MCF-7 cell line treated with Topotecan showed a non-significant increase $(P>0.05)$. In contrast to $\mathrm{Cu}, \mathrm{Zn}-\mathrm{SOD}$ 
activity, the increases in catalase and glutathione peroxidase activities were significant in comparison to the control cells. These increased antioxidant enzyme activites might be considered as a response to increased oxidative stress in cells treated with Topotecan. The results of the study of Sarvazyan et al. (1995) indicate that doxorubicin increases formation of superoxide anion in isolated cardiac myocytes. They propose that intracellular SOD activity protects adult rat cardiomycytes from increased intracellular oxidative stress.

Recent studies demonstrate that increased non-enzymatic and enzymatic antioxidant levels are responsible for enhanced resistance to some anticancer drugs (Russo \& Mitchell, 1985; Kahlos et al., 2001; Chung-man et al., 2001; Ghazizadeh, 2003). These studies suggest that oxygen radical formation caused by these drugs used for chemotherapy might be an alternative mechanism for their cytotoxic effect on cells and antioxidant supplementation should be avoided in cancer patients in order not to prevent chemotherapy-induced apoptosis of cancer cells (Doroshow, 1986; Sinha et al., 1987).

These findings support our hypothesis that Topotecan increases the oxidative stress in MCF-7 cells. However, the mechanisms by which Topotecan increases oxidative stress and if this can be an alternative mechanism for Topotecan toxicity need further investigations.

\section{CONCLUSIONS}

Further studies are needed to clarify why increased oxidative stress was found in Topotecantreated MCF-7 cells. More precisely, Topotecan might induce oxidative stress in a manner independent of its stabilization of the topoisomerase I cleavage complex. Alternatively, increased oxidative stress might be just a side effect caused by inhibition of transcription and replication, induction of DNA damage, necrosis, or apoptosis. In order to discriminate between ROS induced by Topotecan and oxidative stress as a cellular symptom of the lethal inhibition of topoisomerase I, an experimental setup should be designed using cell lines in which the topoisomerase I-DNA cleavage complex is not stabilized by Topotecan (Desai et al., 2003). Thus, a comparison of the amount of oxidative stress in such a cell line with its parental wild type cells would directly resolve this question. These studies may help in developing new strategies for the treatment of cancer.

\section{Acknowledgement}

This study was supported by Akdeniz University Research Fund (project number: 21.01.0122.07).

\section{REFERENCES}

Aebi H (1987) Catalase of enzmatic analysis. In: Enzymes 1: Oxidoreductases, Transferases. Bergmeyer $\mathrm{H}$, ed, pp 273-285. VCH Verlagsgesellschaft, Weinheim.

Akbas SH, Timur M, Ozben T (2005) The effect of quercetin on Topotecan cytotoxicity in MCF-7 and MDA-MB231 human breast cancer cells. J Surg Res 125: 49-55.

Baek SM, Kwon CH, Kim JH, Woo JS, Jung JS, Kim YK (2003) Differential roles of hydrogen peroxide and hydroxyl radical in cisplatin-induced cell death in renal proximal tubular epithelial cells. J Lab Clin Med 142: 178-186.

Baliga R, Ueda N, Walker PD, Shah SV (1999) Oxidant mechanisms in toxic acute renal failure. Drug Metab Rev 31: 971-997.

Bustamante J, Galleano M, Medrano EE, Boveris A (1990) Adriamycin effects on hydroperoxide metabolism and growth of human breast tumor cells. Breast Cancer Res Treat 17: 145-153.

Cakatay U, Telci A, Kayali R, Tekeli F, Akcay T, Sivas A (2003) Relation of aging with oxidative protein damage parameters in the rat skeletal muscle. Clin Biochem 36: 51-55.

Carrard G, Bulteau AL, Petropoulos I, Friguet B (2002) Impairment of proteasome structure and function in aging. Int J Biochem Cell Biol 34: 1461-1474.

Chung-man Ho J, Zheng S, Comhair SA, Farver C, Erzurum SC (2001) Differential expression of manganese superoxide dismutase and catalase in lung cancer. Cancer Res 61: 8578-8585.

Desai SD, Zhang H, Rodriguez-Bauman A, Yang JM, Wu X, Gounder MK, Rubin EH, Liu LF (2003) Transcription-dependent degradation of topoisomerase I-DNA covalent complexes. Mol Cell Biol 23: 2341-2350.

Doroshow JH (1986) Prevention of doxorubicin-induced killing of MCF-7 human breast cancer cells by oxygen radical scavengers and iron chelating agents. Biochem Biophys Res Commun 135: 330-335.

Erlichman C, Boerner SA, Hallgren CG, Spieker R, Wang XY, James CD, Scheffer GL, Maliepaard M, Ross DD, Bible KC, Kaufmann SH (2001) The HER tyrosine kinase inhibitor CI1033 enhances cytotoxicity of 7-ethyl10-hydroxycamptothecin and Topotecan by inhibiting breast cancer resistance protein-mediated drug efflux. Cancer Res 61: 739-748.

Evans P, Lyras L, Halliwell B (1999) Measurement of protein carbonyls in human brain tissue. Methods Enzymol 300: 145-156.

Fairbanks V, Klee GG (1986) Biochemical aspects of hematology. In: Textbook of Clinical Chemistry. Tietz N, ed, pp 1498-1535. WB Saunders Company, Philadelphia.

Geng CX, Zeng ZC, Wang JY (2003) Docetaxel inhibits SMMC-7721 human hepatocellular carcinoma cells growth and induces apoptosis. World J Gastroenterol 9: 696-700.

Ghazizadeh M (2003) Cisplatin may induce frataxin expression. J Nippon Med Sch 70: 367-371.

Gorman A, McGowan A, Cotter TG (1997) Role of peroxide and superoxide anion during tumour cell apoptosis. FEBS Lett 404: 27-33.

Hagiwara SI, Ishii Y, Kitamura S (2000) Aerosolized administration of N-acetylcysteine attenuates lung fibrosis induced by bleomycin in mice. Am J Respir Crit Care Med 162: 225-231.

Hiraoka W, Vazquez N, Nieves-Neira W, Chanock SJ, Pommier Y (1998) Role of oxygen radicals generated by NADPH oxidase in apoptosis induced in human leukemia cells. J Clin Invest 102: 1961-1968. 
Hug H, Strand S, Grambihler A, Galle J, Hack V, Stremmel W, Krammer PH, Galle PR (1997) Reactive oxygen intermediates are involved in the induction of CD95 ligand mRNA expression by cytostatic drugs in hepatoma cells. I Biol Chem 272: 28191-28193.

Hulka BS, Stark AT (1995) Breast cancer: cause and prevention. Lancet 346: 883-887.

Kahlos K, Soini Y, Sormunen R, Kaarteenaho-Wiik R, Paakko P, Linnainmaa K, Kinnula VL (2001) Expression and prognostic significance of catalase in malignant mesothelioma. Cancer 91: 1349-1357.

Kaufmann SH, Peereboom D, Buckwalter CA, Svingen PA, Grochow LB, Donehower RC, Rowinsky EK (1996) Cytotoxic effects of Topotecan combined with various anticancer agents in human cancer cell lines. I Natl Cancer Inst 88: 734-741.

Kinnula K, Linnainmaa K, Raivio KO, Kinnula VL (1998) Endogenous antioxidant enzymes and glutathione $S$ transferase in protection of mesothelioma cells against hydrogen peroxide and epirubicin toxicity. $\mathrm{Br} J$ Cancer 77: 1097-1102.

Koster JF, Biemond P, Swaak AJ (1986) Intracellular and extracellular sulphydryl levels in rheumatoid arthritis. Ann Rheum Dis 45: 44-46.

Levine RL, Garland D, Oliver CN, Amici A, Climent I, Lenz AG, Ahn BW, Shaltiel S, Stadtman ER (1990) Determination of carbonyl content in oxidatively modified proteins. Methods Enzymol 186: 464-478.

Lowry OH, Rosebrough NJ, Farr AL, Randall RJ (1951) Protein measurement with the Folin phenol reagent. I Biol Chem 193: 265-275.

Mans DR, Lafleur MV, Westmijze EJ, Horn IR, Bets D, Schuurhuis GJ, Lankelma J, Retel J (1992) Reactions of glutathione with the catechol, the ortho-quinone and the semi-quinone free radical of etoposide. Consequences for DNA inactivation. Biochem Pharmacol 43: 1761-1768.

Mansat-de Mas V, Bezombes C, Quillet-Mary A, Bettaieb A, D'Orgeix AD, Laurent G, Jaffrezou JP (1999) Implication of radical oxygen species in ceramide generation, c-Jun N-terminal kinase activation and apoptosis induced by daunorubicin. Mol Pharmacol 56: 867-874

Minotti G, Ronchi R, Salvatorelli E, Menna P, Cairo G (2001) Doxorubicin irreversibly inactivates iron regulatory proteins 1 and 2 in cardiomyocytes: evidence for distinct metabolic pathways and implications for ironmediated cardiotoxicity of antitumor therapy. Cancer Res 61: 8422-8428.

Misra HP, Fridovich I (1972) The role of superoxide anion in the autoxidation of epinephrine and a simple assay for superoxide dismutase. J Biol Chem 247: 3170-3175.

Mosmann T (1983) Rapid colorimetric assay for cellular growth and survival: application to proliferation and cytotoxicity assays. I Immunol Methods 65: 55-63.

Muluk NB, Kisa U, Kacmaz M, Apan A, Koc C (2005) Efficacy of Topotecan treatment on antioxidant enzymes and TBA-RS levels in submandibular glands of rabbits: an experimental study. Otolaryngol Head Neck Surg 132: 136-140.

Novak RF, Kharasch ED (1985) Mitoxantrone: propensity for free radical formation and lipid peroxidation - implications for cardiotoxicity. Invest New Drugs 3: 95-99.

Paglia DE, Valentine WN (1967) Studies on the quantitative and qualitative characterization of erythrocyte glutathione peroxidase. J Lab Clin Med 70: 158-169.

Reznick AZ, Packer L (1994) Oxidative damage to proteins: spectrophotometric method for carbonyl assay. Methods Enzymol 233: 357-363.

Russo A, Mitchell JB (1985) Potentiation and protection of doxorubicin cytotoxicity by cellular glutathione modulation. Cancer Treat Rep 69: 1293-1296.

Russo A, Mitchell JB, McPherson S, Friedman N (1984) Alteration of bleomycin cytotoxicity by glutathione depletion or elevation. Int J Radiat Oncol Biol Phys 10: 1675-1678.

Sarvazyan NA, Askari A, Huang WH (1995) Effects of doxorubicin on cardiomyocytes with reduced level of superoxide dismutase. Life Sci 57: 1003-1010.

Simizu S, Takada M, Umezawa K, Imoto M (1998) Requirement of caspase-3(-like) protease-mediated hydrogen peroxide production for apoptosis induced by various anticancer drugs. J Biol Chem 273: 26900-26907.

Sinha BK, Katki AG, Batist G, Cowan KH, Myers CE (1987) Adriamycin-stimulated hydroxyl radical formation in human breast tumor cells. Biochem Pharmacol 36 : 793-796.

Sinha BK, Mimnaugh EG (1990) Free radicals and anticancer drug resistance: oxygen free radicals in the mechanisms of drug cytotoxicity and resistance by certain tumors. Free Radic Biol Med 8: 567-581.

Sladowski D, Steer SJ, Clothier RH, Balls M (1993) An improved MTT assay. J Immunol Methods 157: 203-207.

Somasundaram S, Edmund NA, Moore DT, Small GW, Shi YY, Orlowski RZ (2002) Dietary curcumin inhibits chemotherapy-induced apoptosis in models of human breast cancer. Cancer Res 62: 3868-3875.

Stadtman ER (2002) Importance of individuality in oxidative stress and aging. Free Radic Biol Med 33: 597-604.

Stadtman ER, Levine RL (2000) Protein oxidation. Ann N Y Acad Sci 899: 191-208.

Telci A, Cakatay U, Kayali R, Erdogan C, Orhan Y, Sivas A, Akcay T (2000) Oxidative protein damage in plasma of type 2 diabetic patients. Horm Metab Res 32: 40-43.

Wasowicz W, Neve J, Peretz A (1993) Optimized steps in fluorometric determination of thiobarbituric acid-reactive substances in serum: importance of extraction $\mathrm{pH}$ and influence of sample preservation and storage. Clin Chem 39: 2522-2526

Wenzel U, Nickel A, Kuntz S, Daniel H (2004) Ascorbic acid suppresses drug-induced apoptosis in human colon cancer cells by scavenging mitochondrial superoxide anions. Carcinogenesis 25: 703-712. 